\title{
El Bote de Zamora: historia y patrimonio
}

\author{
J.I. Martín Benito, F. Regueras Grande
}

RESUMEN. En 1911 el cabildo de la catedral de Zamora vendió al anticuario madrileño Juan Lafora unas arquetas, entre ellas un bote de marfil de época califal, valorado en 52.000 ptas. Enterado Gómez-Moreno, que años antes había descubierto la caja ebúrnea en el relicario de la catedral, lo comunicó al diputado nacional Guillermo de Osma, ante el temor de que la pieza saliera de España. El asunto llegó a debatirse en las Cortes con la intervención del presidente del Gobierno, José Canalejas y generó una interesante polémica sobre la propiedad del patrimonio artístico de la Iglesia, de la que se hicieron eco los diarios nacionales. Finalmente, el Estado intervino y compró la pieza, que quedó depositada en el Museo Arqueológico Nacional.

Palabras clave: Bote, arqueta, marfiles, enajenación, arte califal, polémica, Zamora.

ABSTRACT. In 1911 the chapter of the cathedral of Zamora sold Juan Lafora, an antique dealer in Madrid, some coffers; among them was a cylindrical ivory jar that came from the Caliphates' period. It was valued at 52,000 pesetas. Gómez-Moreno, who some years before had discovered the jar in the Cathedral reliquary, spoke about this to Guillermo de Osma, MP, because he feared the piece was going to be taken out of Spain. The affair was the object of a parliamentary question, with a speech by José Canalejas, the Prime Minister. There was an interesting discussion about the ownership of the artistic patrimony of the Church, which was widely reported on the national newspapers. The Government eventually acted and bought the piece, which was put on display in the National Museum of Archeology. Key words: cylindrical jar, coffer, ivory, secularization, Caliphate art, controversy, Zamora.

“Esta es la historia de nuestra codicia pequeñita, de nuestra dejadez y de nuestro despilfarro" (J.A. GAYA NUÑO; La pintura española fuera de España, Madrid, 1958, 13.

\section{INTRODUCCIÓN}

Cuando hace un par de años, con ocasión de celebrarse Las Edades del Hombre IX. Remembranza, los zamoranos se regocijaban de la vuelta "a casa" del Bote califal ${ }^{1}$

1 A. FRANCO, "Bote de Zamora", Las Edades del Hombre. Remembranza, Zamora 2001, p. 65. Sin embar- procedente de su Seo, por el que tanto se había bregado para que acudiera, la mayoría desconocían (u olvidaban) no sólo las lamentables circunstancias de su enajenación, sino que ésta no fuese sino el primer episodio (conocido) de un rosario de ventas diocesanas que salpican todo el siglo $X X^{2}$.

go, pasó absolutamente desapercibida la arqueta almorávide, asimismo procedente de la catedral y hoy también en el MAN.

${ }^{2}$ El caso, naturalmente, es extensivo a toda España y a las tierras y diócesis castellanas en particular, desde las andanzas de Guerra Junqueiro en el siglo XIX, a las colecciones Marés, Godia o la más modesta Fontaneda, que han reclutado entre nosotros una parte 
Por citar sólo dos casos muy señalados -aparte las cinco arquetas árabes que en 1911 y 1926 acompañaron al Bote (ver infra)- ambos procedentes de la propia catedral zamorana, no conviene olvidar la venta (por 900000 pts) de los tapices ${ }^{3}$ de Tideo y El paso del Mar Rojo al Ayuntamiento de

sustancial de sus piezas: la colección Guerra Junqueiro se conserva en su Casa museo de Oporto y en el Museu Nacional de Arte Antiga de Lisboa. Respecto.a la de Federico Marés, véase: VV. AA.; Museu Marés. Catàleg d'escultura y pintura medievals, Barcelona 1991, fundamentalmente imaginería lignea., passim. VV. AA.; Museu Marés. Catàleg d'escultura i pintura dels segles XVI, XVII y XVIII, Barcelona 1996, passim, incluso muchas de procedencia desconocida. Sobre la de Francisco Godia: VV.AA.; Románico y gótico de la colección Francisco Godia, Barcelona 2001, donde abundan las piezas procedentes de la región leonesa. Por fin: $\mathrm{C}$. FONTANEDA Y J.A. LEÓN, La colección Eugenio Fontaneda y el castillo de Ampudia, Palencia 2001. Aparte de los libros, ya clásicos, de J. A. GAYA NUÑO; La pintura española fuera de España, Madrid 1958 y La pintura europea fuera de España, Madrid 1960, también se han dedicado al tema: J.M. MERINO DE CÁCERES; “El "elginismo" en España: algunos datos sobre el expolio de nuestro patrimonio monumental", Revista de Extremadura 2, 1990, pp. 39-70, con bibliografía anterior. De tono más divulgativo: G. SANTONJA; Castilla y León. Lo que se llevaron de esta tierra, Valladolid, Biblioteca de "El Norte de Castilla", 1994. Recientemente (noviembre de 2002) se celebraron en Madrid las XI Jornadas de Arte del Departamento de Historia del Arte (CSIC) dedicadas al tema que nos ocupa: M. Cabañas Bravo (coordinador); El arte español fuera de España, Biblioteca de Historia del Arte 6, Madrid 2003. Cada vez es mayor la conciencia del significado y secuelas del expolio y empiezan a aparecer publicaciones específicas. Sobre la emigración del patrimonio artístico altoaragonés: A. NAVAL MAS; Patrimonio emigrado. Publicaciones y Ediciones del Alto Aragón, Huesca 1999. Sobre el monasterio de Santo Domingo de Silos: A. C. IBÁÑ̃ZZ PÉREZ, "La desamortización en Silos", Silos. Un milenio IV Arte, Studia Silensia XXVIII, Universidad de BurgosAbadía de Silos, 2003, pp. 385-424. Dejamos de lado las actividades más rocambolescas de los Erik el Belga, traperos, mohatreros y robacepillos que encontraron en estas tierras presas (y cómplices) tan fáciles como apetecibles.

${ }^{3}$ Sobre el asunto, ver: J. P. AsSELBERGHS, Los tapices flamencos de la catedral de Zamora, Caja Duero, Salamanca 1999, 40-42. Últimamente se ha vuelto a insistir sobre ambos (sin citar a Asselbergs): L. RODRÍGUEZ PeINADO Y V. LÓPEZ HeRVÁs, “Los tapices góticos del Ayuntamiento de Madrid", De Arte 1, 2002, pp. 55-63.
Madrid después de una larga negociación entre 1944 y 1946 que tuvo, como veremos, muchas concomitancias con la operación de principios de siglo y que asimismo contó con la oposición de un único canónigo; y como esperpéntico colofón de la centuria, el expolio (detectado en 1996) de casi 500 volúmenes, entre ellos diez incunables, del fondo antiguo de la Biblioteca del Archivo diocesano ${ }^{4}$, de los que sólo se ha recuperado el $40 \%$

Cien años después del descubrimiento del bote, y de su insidiosa expatriación, es momento quizás de reflexionar sobre aquellos lamentables sucesos que no sólo no han servido de escarmiento si no que, en su trasfondo ideológico, aunque hayan perdido intensidad, mantienen intacta su vigencia. Porque, como diría Gaya Nuño, la cuestión no es "de huevo, sino de fuero; no de cantidades de dinero, sino de proporciones de honor"y a ello dedicaremos las páginas que siguen.

\section{EL CONTEXTO.}

El siglo XIX marcó definitivamente la época de los grandes descubrimientos patrimoniales nacionales e internacionales ${ }^{5}$. Los primeros sirvieron de fundamento y memoria de los estados-nación, entonces en plena época de afirmación patriótica y política, los segundos de disputa imperialista entre las grandes potencias europeas: Francia e Inglaterra, con la incorporación posterior de Alemania (y Estados Unidos) y sus grandes museos, símbolos de su poder (Louvre, British Museum, Kaiser-FriedrichMuseum, por citar los más notables).

\footnotetext{
${ }^{4}$ Véase información: ABC Castilla y León, Valladolid, martes 28 de noviembre de 2000, plana 8 .

5 J.M. Delaunay, "La Dama de Elche, actriz de las relaciones francoespañolas del siglo XX", en R. Olmos y T. Tortosa (eds.). La Dama de Elche. Lecturas desde la diversidad, Madrid, 1997, pp.101.
} 
España, al contrario, estado frágil y dependiente de aquellas potencias vio como buena parte de sus hitos patrimoniales acabaron, por distintas vías, en manos de sus vecinos imperialistas En realidad, hasta el siglo XIX el arte español, salvo curiosidad pintoresca (Mezquita de Córdoba, La Alhambra, etc ${ }^{6}$ ) o excepción que confirma la regla (Murillo ${ }^{7}$ ), apenas era conocido fuera de nuestras fronteras, ni tampoco había sido estudiado, ni sistematizado. El rubicón del proceso fue la Guerra de la Independencia $^{8}$ en la que se sucedieron depredaciones y saqueos artísticos (Mariscales Soult ${ }^{9}$ y Sebastiani, José Bonaparte etc) cuando no ventas (marchantes ${ }^{10}$ británicos $\mathrm{y}$ franceses, en menor medida) $\mathrm{u}$ "obsequiosos reconocimientos" (entrega por Fernando VII de las 165 pinturas recuperadas en la batalla de Vitoria, pertenecientes a la Colección Real, al Duque de Wellington ${ }^{11}$ ) que abrieron paso a una gran expatriación patrimonial que no ha cesado durante más de 150 años. Gracias a ello, sin embargo, el arte hispánico, ha adquirido carta de naturaleza y universal reconocimiento

\footnotetext{
${ }^{6}$ Girault DE PRANGEY, J.P.; Monuments arabes et moresques de Cordove, Seville et Grenade. Souvenirs de Grenade et de l'Alhambre, Mosquée de Cordove, Giralda et Alcazar de Seville, Paris, 1836-1839.

${ }^{7}$ J. A. GAYA NuÑO, 1958, p. 15. Ma DE LOS SANTOS GARCÍA FELGUERA; Viajeros, eruditos y artistas. Los europeos ante la pintura española del siglo de oro, Madrid, 1991, pp. 30-35.

${ }^{8}$ GAYA NUÑO, 1958, "Historia de una evasión", pp. 16 y ss. SANTOS FELGUERA, 1991, pp. 51-60.

${ }^{9}$ GAYA NUÑO, 1958, pp . 17 y 18 referidas a ambos mariscales. El equipaje de José Bonaparte, incautado por Wellington después de la batalla de Vitoria (1813) incluía 165 cuadros de la colección real.

${ }^{10}$ GAYA NUÑO, 1958, p. 17 y SANTOS FELGUERA, 1991, pp. 42-49

${ }^{11}$ La versión británica de los hechos, en: T. CROMBIE; "The Legacy of Vitoria. Spanish Painting at Aspley House", Apollo, vol. XCVIII, no 139, septiembre de 1973, pp. 52-57. Toda la revista está dedicada a las colecciones del duque de Wellington. La interpretación española, siempre apasionada, de GAYA NUÑO, 1960, pp. 99-103.
}

Por lo que se refiere a la pintura el salto cualitativo (y cuantitativo) en este vaciamiento y expropiación monumental coincidió con las especiales circunstancias propiciadas por la legislación desamortizadora $^{12}$ de los años treinta ${ }^{13}$. Aprovechando tan tentadora oportunidad -y con la inestimable complicidad de la familia Madrazo ${ }^{14}$ -en un momento además en el que España se había convertido en el país romántico ${ }^{15}$ por antonomasia, el rey Luis Felipe de Orleans envía una comisión que realiza una compra masiva de cuadros. La famosa Galería Española de Luis Felipe ${ }^{16}$, instalada en el Louvre entre 1838-1848, se convirtió en un auténtico revulsivo de la revolución naturalista, antesala del Impresionismo y clave en la evolución del arte moderno ${ }^{17}$.

-

12 J. J. MARTín GONZÁLEZ, "Problemática de la desamortización en el arte español", II $I^{o}$ Congreso Español de Historia del Arte. "El arte del siglo XIX", Valladolid 1978, pp 15-29.

${ }^{13}$ Que, por cierto, dio lugar a la primera interpelación parlamentaria con la protesta del diputado de Cádiz y el propio Mendizábal por la venta de los Zurbaranes de la Cartuja de Jerez, aunque todo quedó en agua de borrajas.

${ }^{14}$ SANTOS FELGUERA, 1991, p. 90.

${ }^{15}$ Sobre la Imagen romántica de España, ver los distintos trabajos del catálogo con el mismo nombre, Madrid 1981.

${ }^{16}$ J. Baticle, C. Marinas, C. Rossart y CH. PerRIER; La Galerie Espagnole de Louis-Philippe au Louvre 1838-1848, Notes et Documents 4, Paris 1981.

${ }^{17}$ Desde la celebración del cuarto centenario del nacimiento de Velázquez (1999) han abundado las publicaciones, normalmente fuera de España, sobre el papel desempeñado por los pintores españoles en la revolución antiacadémica del siglo XIX. La bibliografía reciente la precede I. HEMPEL LIPSCHHUTZ; La pintura española y los románticos franceses, Madrid 1988 (original inglés de 1972). VV. AA. Les peintres français et l'Espagne. De Delacroix a Manet. Catálogo de la Exposición. Museo Goya, Castres 1997. VV. AA. Velazquez et la France. La découverte de Velazquez par les peintres français. Catálogo de la Exposición, Museo Goya, Castres 1999. Manet Velazquez. La manière espagnole au XIX siècle. Catálogo de la Exposición. Museo d'Orsay, Paris 2002. Manet/Velazquez. The French Taste for Spanish Painting. Catálogo de la Exposición. Museo Metropolitano, Nueva York 2003, con algunos trabajos suplementarios respecto al catálogo francés. 
Vendida después en Londres (1852) su dispersión generó buena parte de las colecciones de pintura española en los museos europeos (y luego americanos).

Pero no fue sólo la pintura, el sensacional hallazgo del tesoro de Guarrazar (1859), comprado mayoritariamente por el Museo de Cluny (París) dio a conocer el extraordinario boato tardoantiguo de los monarcas visigodos en lo que entonces se denominaba arte latino-bizantino, antesala del reconocimiento (y deslinde) del prerrománico hispano. En la arqueología peninsular dos hitos marcan además el ultimo cuarto del siglo XIX: el descubrimiento del arte rupestre paleolítico ${ }^{18}$ negado y ninguneado (Congresos de Lisboa, 1880 y La Rochelle, 1882) durante varias décadas, por los "intelectuales orgánicos", de la prehistoria europea y el hallazgo de la Dama de Elche $(1897)^{19}$, pronto emigrada al Museo del Louvre, fundamental para el conocimiento y desarrollo del arte ibérico. Su venta será el detonante que inicie el proceso de una Ley de Patrimonio, voluntad ya en el ambiente desde la segunda mitad del siglo XIX, pero que no culminará hasta la Ley de 1911 y su reglamento del año siguiente. Todo ello -y no espigamos más que los ejemplos cardinales- fueron piedra de toque de ese nuevo discurso histórico que es lo que hoy denominamos arte español.

\footnotetext{
${ }^{18}$ J. CARBALLO; Descubrimiento de la cueva y pinturas de Altamira por Don Marcelino S. de Sautuola, Santander 1950. Estudio y comentarios sobre el descubrimiento y su polémica posterior. Incluye facsímil de: M. S. DE SAUTUOLA; Breves apuntes sobre algunos objetos prehistóricos de la provincia de Santander, Santander 1880.

${ }^{19}$ Coincidiendo con el centenario de su descubrimiento (1897) se han publicado varias obras sobre el tema que afectan a la profunda relectura que se viene haciendo en los últimos años del arte ibérico: OLMOS Y TORTOSA (eds.) 1997.
}

Un arte, en cualquier caso, cuyo componente oriental ${ }^{20}$ (árabe-islámico) fascinó siempre a los viajeros y amateurs extranjeros y se naturalizó hasta tal punto entre los propios españoles que llegó a valorarse como el más genuinamente nacional (recuérdese el mudéjar) exportándose su imagen en ocasiones tan señaladas como el pabellón español de Exposición Universal de París de 1878 , por no citar la eclosión de todo el neomudéjar posterior.

Dentro del arte cordobés califal destaca por su refinamiento la eboraria ${ }^{21}$ (estuches de juegos, botes -huqqa-, arquetas safat-, etc), arte por excelencia de la corte de los Omeyas. Los destinatarios de dichos trabajos en marfil, sus mecenas y probablemente sus artistas ejecutores eran personajes que pertenecían al círculo más íntimo del califa, y el lugar de realización, la ciudad palaciega de Madînat al- Zahrâ. Eran, pues, por su exquisitez formal y significado político, la expresión misma del poder ${ }^{22}$.

Aunque no conservemos ningún objeto de marfil vinculado con Almanzor, un texto redactado hacia 1260 (Poema de Fernán González) por un monje de San Pedro de Arlanza menciona el rico botín en cajas ebúrneas recuperado de la tienda del dicta-

\footnotetext{
${ }^{20}$ Componente exótico, expresionista, anticanónico, castizo, que está asimismo en la base de la rehabilitación de El Greco -otro de los pilares del nuevo "arte español"- como uno de los grandes maestros del Manierismo: J. ÁlvAREZ LOPERA; De Ceán a Cossio: la fortuna crítica de El Greco en el siglo XIX, Madrid 1987, vol. II.

${ }^{21}$ Las obras fundamentales para su estudio son las siguientes: J. FERRANDIS; Marfiles árabes de Occidente, 2 vols., Madrid 1935. J. BECKWITH; Casket from Cordoba, Londres 1960. E. KÜHNEL; Die islamische Elfenbeininskulpturen, Berlín 1971.

${ }^{22}$ G. MARTÍNEZ GROS Y S. MAKARIOU; “Arte y política en Al-Andalus, siglos X y XI", en Las Andalucías de Damasco a Córdoba, París 2000, pp. 72-79 y sobre todo 76-79. J. ZOZAYA; “El objeto de arte como expresión del poder califal", El Islam y Cataluña, Barcelona 1998, pp. 113-119.
} 
dor amirí en el campo de Medinaceli, donde encontró la muerte. Las cajas fueron ofrecidas a dicho monasterio por el conde Fernán González y colocadas encima del altar, probablemente sobre la viga de gloria, como triunfalmente convertidas.

Fallaron ay de marfil arquetas muy preciadas con tantas de nobleza que no podían ser contadas. Fueron para San Pedro las arquetas donadas; Están en este día en el altar asentadas.

Un origen similar debió de ser el del bote y cajitas zamoranas ${ }^{23}$. Como tantos tesoros de muchas iglesias hispánicas, estas preciosidades ebúrneas serían ofrecidas por reyes y señores como el más rico presente conseguido de los infieles y convertidos en objetos sagrados ${ }^{24}$. En nuestro caso desconocemos fecha y donante aunque GómezMoreno $^{25}$ supuso que sería parte del botín

\footnotetext{
${ }^{23}$ En total seis. En primer lugar un bote y una arqueta que por decirlo con palabras de su descubridor Manuel Gómez-Moreno "...después de vicisitudes lamentables, entraron en nuestro Museo Arqueológico Nacional, en 1911. Las tres siguientes [arquetas y un bote], por lo menos, han ido ahora (1926) a un coleccionista madrileño, sin formalidades legales: huelgan los comentarios": M. Gómez MORENO, Catálogo Monumental de España. Provincia de Zamora, Madrid 1927, T. I, p. 81 y T. II, Láms. 24 (nº 164), Lám. 31, (nº165), ambas en el M.A.N. Lám 33, (nº166 y 167, pequeño bote liso), Lám. 37 (n⿳⺈ 168). El bote 164, según reza inscripción cúfica, es del 964; la 165 y 167 son del siglo XII, ésta última adquirida por la colección Castillo Olivares contenía las reliquias de Martín Cid, fundador del monasterio de Valparaíso; el bote 170, es del siglo XII asimismo, colección Castillo Olivares, la arqueta 166, del siglo XIV, de la misma colección, arqueta 168, siglo XIV, colección Castillo Olivares.

${ }^{24}$ S. MAKARIOU; "La Pyxide du trésor de la cathédrale de Narbonne", Cahiers Archéologiques 1999, pp. 127-135.

${ }^{25}$ El maestro granadino se refirió a la eboraria califal en varios momentos, aparte el Catálogo de Zamora:"Los marfiles cordobeses y sus derivaciones", Archivo Español de Arte y Arqueología, III, 1927, pp. 233-243 y 29 grabados fuera de texto. Ars Hispaniae III. El arte árabe español hasta los almohades. Arte mozárabe, Madrid 1951, pp. 297-310. Considera dos maestros principales dentro de los talleres cordobeses, el anónimo que llama "de Zamora" que representa la adopción del estilo ornamental de la mezquita de Córdoba a la talla
}

conseguido por Fernando III, en la conquista de Córdoba (1230) y que el rey Santo lo regalaría a la catedral zamorana en cuyo relicario, conteniendo "piedras de los Santos Lugares" quedó al abrigo de miradas curiosas durante cerca de siete siglos.

\section{EL DESCUBRIMIENTO DEL BOTE.}

Efectivamente, el descubrimiento del bote de Zamora coincidió con una de las varias visitas (1903-1904) que el joven matrimonio Gómez-Moreno realizó a la provincia para la redacción del Catálogo Monumental de Zamora.

La idea de un Catálogo Monumental de España está estrechamente relacionado con el espíritu regeneracionista posterior al desastre del 98: un estudio y catalogación preciso del patrimonio que evitase su merma y deterioro, alarmante después de un siglo de abandono, guerras y desamortizaciones $^{26}$. El mentor de la obra fue Juan Facundo Riaño ${ }^{27}$, institucionalista granadino, director de Academia de San Fernando, organizador del Museo de Reproducciones Artísticas y valedor del joven Manuel Gómez-Moreno. Entendido en artes suntuarias hispánicas (fue autor del Catálogo de artes industriales hispánicas del Victoria and Albert Museum: The industrial art in Spain, Londres 1877), su relación con Pascual Gayangos del que acabaría siendo yerno le formó como experto arabista y propietario de dos botes califales que luego pasaron al

en marfil. Su obra principal sería el bote de Zamora y un pebetero de muy poca altura en el Museo Victoria and Albert de Londres. El otro maestro, probablemente forastero, ajeno a lo cordobés, Halaf, firmó dos obras, el bote de la Hispanic Society de Nueva York y la arqueta de Fitero (Navarra).

${ }^{26}$ Ma E. GÓMEZ-MORENO; La Real Academia de San Fernando y el origen del Catálogo Monumental de España, Madrid 1991, pp. 9 y ss.

${ }^{27}$ Ma E GÓMEZ-Moreno; “Los Riaño”, en Manuel Gómez-Moreno Martínez, Madrid 1995, pp. 77-82. 
Museo del Louvre y al londinense de South Kensington.

La tarea del CME fue obra sin precedentes en Europa y la elección para iniciarla de un desconocido Manuel Gómez-Moreno Martínez indignó a los viejos y sesudos estudiosos (Amador de los Ríos, Rada y Delgado) que, sin embargo, quedaron entusiasmados tras la redacción del primer catálogo de Ávila en 1901.

En Zamora, la primera campaña discurrió entre los meses de julio y noviembre de 1903. Posteriormente el joven matrimonio efectuó un segundo viaje entre julio y agosto de 1904. El 14 de junio -nos informa Maria Elena Gómez-Moreno- arriban a Zamora después 12 horas de tren desde Madrid. Desde allí realizan viajes cortos con regreso a la capital y dos excursiones más largas, una a Benavente, que les permite visitar Santa Marta de Tera, San Román del Valle y San Esteban de Nogales (de donde da cuenta, ya en manos privadas, de la arqueta de esmaltes recién recuperada por el Museo de León) y otra de ocho días recorriendo Villalpando, Castroverde, Corrales, Fuentesaúco y Fuentelapeña.

De nuevo en Zamora la tarea principal consistía ahora en la apertura de los relicarios de la catedral, una vez obtenidos los prescriptivos permisos. Elena, su mujer, subida a una escalera le iba alargando las piezas: arquetas pintadas, talladas, cinceladas, de marfil, de esmaltes, grandes y chicas. De repente una emoción sacudió su rostro, un grito exultante, una emoción que siempre recordaría, cuando tuvo en sus manos el espléndido huqqa, primoroso bote de marfil que entregó embargada de alegría a Manuel como la presea más maravillosa del relicario. Desde entonces -recuerda María Elena- sería para su madre "su bote".
Lo que fue joyero que el califa Alhaquén II mando labrar para su favorita vascongada $\mathrm{Zabh}^{28}$ (Aurora), por el nacimiento de su hijo y heredero frustrado, Abderrramán, si no hubiera muerto prematuramente, se había convertido en piadosa teca conteniendo piedras de los Santos Lugares. A pesar de ignorarse su existencia, como la del resto de arquetas árabes, todas se encontraban registradas ya en el tesoro de la catedral en 1367, en el relicario después de 1436 e inventariadas con más pormenor en 1558 y 1578.

\section{LA VENTA.}

Cuando el cabildo fue consciente de la importancia de la pequeña joya que atesoraba su relicario, no dudó en enviarla a la exposición de arte retrospectivo celebrada en Santiago de Compostela, donde por vez primera el bote zamorano salía a la luz pública puesto que el Catálogo Monumental de Gómez-Moreno permanecerá inédito hasta 1927.

Años después (1911) acabaría vendiéndolo, junto con otra arqueta, ( Lám. II) a Juan Lafora y Calatayud que con Rafael García Palencia, era, en opinión de Marés ${ }^{29}$, el mejor anticuario madrileño de la segunda década del siglo XX.

En su tienda de la Carrera de San Jerónimo 51 se daban cita, al atardecer "académicos, historiadores, arqueólogos, investigadores y coleccionistas; entre ellos... Pablo Bosch, Marqués de Valverde [implicado en el affaire del bote Zamorano], conde de las Almenas, José Florit, conservador de la Real Armería, José Weissberger, Conde de Casal, Conde de Vinaix,

\footnotetext{
${ }^{28}$ El epígrafe, en bellos caracteres cúficos, reza: "Bendición de Dios para el Imán 'Abd Allah al-Hakin al Mustansir billah, Príncipe de los creyentes. Esto es lo que ordenó se le hiciera a la Señora Madre de 'Abd al-Rahman III al cuidado de Durri el Chico. Año de tres y cincuenta y trescientos" (964 d. C.).

${ }^{29}$ MARÉS, 1977, p. 248.
} 
Antonio Vives, Felix Boix, y no pocas veces el propio director de la Real Academia Española, Alejandro Pidal Mon..." Marés trazó de él una imagen de hombre inteligente, sensible y enamorado de sus piezas, atribuyéndole el descubrimiento, "a la luz de una cerilla" de la firma de Van der Goes en la famosa Epifanía que luego mentaremos.

La dilapidación de buena parte del patrimonio histórico y artístico de la Iglesia (ni sólo zamorana, ni sólo entonces) recorría toda la geografía eclesiástica, desde la cabecera de los obispados hasta los rincones más recónditos de las diócesis. En ocasiones, las menos, la venta generó protestas por parte de los feligreses. En la provincia de Zamora, el mismo año que se vendieron las arquetas andalusíes, tuvo lugar en Villafáfila, entonces diócesis de Astorga, una manifestación ${ }^{30}$ de protesta en la plaza mayor, protagonizada en su mayoría por mujeres y niños y en la que tuvo que intervenir la Guardia Civil, por las sospechas de que el cura había vendido a un anticuario una efigie de Jesús Nazareno. En general la polémica acababa en agua de borrajas. Sirva otro ejemplo cercano, la venta en 1904 de dos cuadros de El Greco por los canónigos de la catedral de Valladolid, hoy en la Frick Collection de Nueva York y el Museum of Fine Arts de Montreal. La enajenación fue enérgicamente denunciada por la prensa y la Academia de la Purísima Concepción subrayando el vacío legal que permitía la expatriación masiva de nuestro patrimonio. En la polémica se plantearon problemas similares a los de la venta del Bote zamorano (ver infra): capacidad o no del cabildo para efectuar enajenaciones eclesiásticas y justificación de éstas por falta de recursos (para comprarse un órgano). ${ }^{31}$

\footnotetext{
${ }^{30}$ El Heraldo de Zamora y El Correo de Zamora, 15 de mayo de 1911.

31 J. C. BRASAS EGIDO; “Crónica de una pérdida irreparable del Patrimonio artístico vallisoletano. La
}

De nuevo a nuestro bote, su enajenación hay que situarla en el contexto más amplio -como se hizo en Valladolid y en tantos otros sitios- de venta de objetos litúrgicamente inservibles que permitían allegar fondos a las muy maltrechas arcas episcopales, zafia argumentación que de nuevo se ha orquestado sin el más mínimo pudor durante el gran expolio eclesiástico y parroquial de los años sesenta y setenta del siglo XX.

De modo que la venta de los marfiles hispano-árabes zamoranos contaba no sólo con precedentes, menos notables, pero que funcionaban (y seguirán funcionando) como justificación de una actitud considerada legítima.

Parece que pronto los miembros del Cabildo se dieron cuenta de lo que suponía expropiar ciertos objetos, aparentemente "muy deteriorados y que no prestaban servicio alguno en la Catedral ${ }^{32 "}$; sobre todo, cuando se sucedían las pujas de los anticuarios. En 1906 la Corporación tomó clara conciencia del valor de estas piezas cuando las ofertas por la compra de algunos alfombras y objetos antiguos comenzó a dispararse. En la reunión de 14 de abril de aquel año, el deán informó de una instancia que el vecino de Zamora, Fernando Martínez, había dirigido al obispo, pidiéndole que éste autorizara al Cabildo "para enajenar algunas alfombras y otros objetos antiguos muy deteriorados, los cuales justipreciaba en novecientas noventa pesetas". Cuatro días más tarde el canónigo fabriquero manifestaba que había recibido otras propuestas: una ofrecía "la cantidad de dos mil pesetas aun después de retirar una de las

\footnotetext{
venta de dos cuadros de El Greco que pertenecieron a la catedral y la intervención de la Real Academia de Bellas Artes de la Purísima Concepción", Boletín de la Real Academia de Bellas Artes de la Purísima Concepción de Valladolid, 28, 1993, pp. 119-127.

32 Archivo catedralicio de Zamora. Actas capitulares. Lib. 156. Palabra de 18 de abril de 1906.
} 
alfombras y la imagen deteriorada de un ángel"; la otra, la de un anticuario de Granada, alcanzaba las cuatro mil pesetas. Ante estas ofertas, y sólo con la oposición del capitular Tascón, el Cabildo decidió la enajenación de los objetos, eso sí, con las debidas autorizaciones ${ }^{33}$. Sin embargo, en los días siguientes, la puja continuó recibiéndose nuevas ofertas, una de 4.250 ptas y otra de 6.000 ptas, por lo que, ante este incremento, el Cabildo "acordó esperar hasta ver lo que más conviene $^{\prime \prime 34}$. La espera duró hasta marzo de 1907, cuando los anticuarios volvieron a insistir. El deán llevó personalmente las negociaciones $\mathrm{y}$, "después de regatear cuanto le había sido posible", convino la venta con los anticuarios en 8.250 ptas, lo que el Cabildo "aprobó gustosísimo" 35 .

$\mathrm{Al}$ año siguiente, el Cabildo volvió a acordar la venta de "algunas prendas y trapos desechados por inservibles", tasados por un perito anticuario en 9.000 ptas. Con ello pensaban los capitulares poder "atender á remediar algunas necesidades en el caso de que dichos objetos se vendieran" ${ }^{\prime \prime}$.

Con estos precedentes, insistimos, nada extraña la disposición de los canónigos zamoranos a enajenar bienes de la catedral, lo que se consumó con la venta de las arquetas árabes que se guardaban en el Relicario desde la Edad Media y que había descubierto Gómez Moreno. El interés por los anticuarios, y más en concreto por Juan Lafora, se despertó tras la Exposición Regional Gallega celebrada en Santiago de Compostela en 1910, donde las cajitas andalusís tuvieron su puesta de largo. En mayo

-

${ }^{33}$ Archivo catedralicio de Zamora. Actas capitulares. Lib. 156. Palabra del 18 de abril de 1906, fol. 79.

${ }^{34}$ Archivo catedralicio de Zamora. Actas capitulares. Lib. 156. Palabra del 3 de abril de 1906.

${ }^{35}$ Archivo catedralicio de Zamora. Actas capitulares. Lib. 156. Palabra del 9 de marzo de 1907, fol. 99.

${ }^{36}$ Archivo catedralicio de Zamora. Actas capitulares. Lib. 156. Palabra del 9 de febrero de 1908, fol. 126. y junio de ese año trataba el Cabildo sobre el envío de las citadas arquillas a la muestra de compostelana. La Junta organizadora de la Exposición había insistido varias veces en que la Iglesia de Zamora presentara algún objeto para la sección de Arqueología y así se lo hizo saber el obispo al Cabildo. Finalmente, éste acordaba el 9 de julio, "enviar á la Exposición de Santiago algunas arquillas que se habían hallado en el Relicario y que tenían valor artístico y arqueológico" ${ }^{37}$.

En la reunión del Cabildo de 23 de febrero de 1910, informaba el deán que "por algunos anticuarios se le venían haciendo proposiciones para adquirir objetos de esta Santa Iglesia, unos deteriorados y sin uso, y otros fácilmente sustituibles por nuevos y menos valiosos, á saber: algunas albas viejas, las cajas que se llevaron recientemente á la Exposición Regional Gallega, y telas y doseles que se colocan en los altares del Claustro para la procesión de la Octava de Corpus Christi". Tras el informe del deán, el Cabildo, "con el voto en contra y la protesta del sr. Arcipreste, acordó vender dichos objetos antiguos, si realmente se ofrecía por ellos precio digno de ser aceptado, ya que la fábrica de la Iglesia se halla bien necesitada de recursos". Seguidamente, los capitulares acordaron guardar absoluta reserva de este asunto ${ }^{38}$.

En marzo de 1910 ya se había solicitado y obtenido del Nuncio Apostólico la autorización para la venta de dichos objetos, permiso sobre el que se centrará buena parte de la polémica en las Cortes (ver infra) cuando un año después se debata la venta de las arquetas. En la reunión de 17 de marzo el deán informa al Cabildo de la nueva emisión de obligaciones que la so-

\footnotetext{
${ }^{37}$ Archivo catedralicio de Zamora. Actas capitulares. Lib. 156. Palabras de 19 de mayo, 6 de julio y 9 de julio de 1909.

${ }^{38}$ Archivo catedralicio de Zamora. Actas capitulares. Lib. 156. Cabildo ordinario de 23 de febrero de 1910,fols. 185 v y 186 r.
} 
ciedad hidroeléctrica "El Porvenir de Zamo$r a^{\prime \prime}$ había anunciado, al tiempo que proponía "emplear en esos valores las existencias en metálico que posée la fábrica de esta Santa Iglesia, y el importe de las ropas y objetos antiguos para cuya enajenación se ha impetrado y obtenido del Revmo. Sr. Nuncio Apostólico la autorización competente". Todos los capitulares estuvieron de acuerdo en invertir el dinero en "valores de algún modo productivos, mientras no haya de hacerse del mismo el uso que exijan las necesidades de la fábrica". Sin embargo, donde no hubo acuerdo fue en el destino de la inversión: la mitad del Cabildo era partidaria de adquirir acciones de la citada empresa, mientras que la otra prefería comprar títulos de la Deuda Pública ${ }^{39}$. Finalmente, tras la venta, el Cabildo se decidió por esta última operación por el mismo valor en que se habían liquidado los marfiles, esto es, $52.500 \mathrm{ptas}^{40}$, lo que no fue óbice para que se descuidasen las inversiones en la empresa hidroeléctrica. En reunión de 18 de octubre de 1911, el deán, "respondiendo á la Comisión que le confirió el Ilmo. Cabildo, manifestó haber hecho la transferencia de las acciones del "Porvenir de Zamora", propiedad del Cabildo, a favor del Capitular sr. Mateos" $^{\prime 4}$.

Por todo ello, gran sorpresa debió causar en el Cabildo -resuelto como estaba a la enajenación de dichos objetos- la petición del ministerio de Instrucción Pública y Bellas Artes de "tres arquillas árabes" con destino a la exposición a celebrar en $\mathrm{Mu}$ nich sobre Arte mahometano. En la reunión de 10 de julio de 1910, los canónigos decidieron aplazar la decisión sobre el préstamo

\footnotetext{
${ }^{39}$ Archivo catedralicio de Zamora. Actas capitulares. Lib. 156. Cabildo de 17 de marzo de 1910, fol. 188.

${ }^{40}$ Archivo catedralicio de Zamora. Libro de Contaduría de Hacienda de 1911-13,1921, 1923, 1925, 1926, pág. 8.

${ }^{41}$ Archivo catedralicio de Zamora. Actas capitulares. Lib. 156. Cabildo de18 de octubre de 1911, fol. 258 $\mathrm{v.}$
}

de las piezas "por la gravedad del asunto", hasta que el obispo regresara de la visita $a d$ limina. Desconocemos si llegaron a prestarse.

Lo que lamentablemente sí se produjo fue la venta que debió de consumarse en los últimos días de febrero de 1911. El obispo (a la sazón Luis Felipe Ortiz y Gutiérrez) había recomendado que para proceder a la transferencia de los objetos antiguos, se solicitara la autorización del Papa. En la reunión (palabra) de 16 de febrero de 1911, el deán dio cuenta al cabildo de que su Santidad había otorgado su venia, con la condición de que la mitad del valor se aplicara a la fábrica de la catedral y la otra mitad a la mesa capitular, al tiempo que se celebraran dos aniversarios por las personas que los habían donado. Llama la atención la valoración que el deán, Estanislao de Cuadra, hacía de las piezas: "de escasísimo valor intrínseco y de ninguna utilidad para su uso, pero de mucha estimación en el mercado de antigüedades". Parece que fue el propio deán quien se encargó personalmente de la venta, pues en las actas capitulares consta que el Cabildo, oídas sus manifestaciones, aprobó las actuaciones y autorizó "la realización de la venta en las condiciones y por el precio convenido por él". De todo ello acordaron bajo juramento guardar reserva absoluta e informar de ello a los canónigos arcipreste, doctoral y magistral, ausentes de la reunión ${ }^{42}$.

En los días siguientes, el deán escribió al anticuario Juan Lafora, notificándole la aceptación por parte del Cabildo de la oferta que éste había hecho por los marfiles. De ello dio cuenta en el cabildo ordinario de 22 de febrero. El acuerdo fue contestado por el arcipreste, tal como se recoge en las actas de la sesión: "El sr. Arcipreste se opuso á

\footnotetext{
${ }^{42}$ Archivo catedralicio de Zamora. Actas capitulares. Lib. 156. Palabra del 16 de febrero de 1911, fol. 227.
} 
la venta por las razones que expuso la primera vez que se trató este asunto, y si bien se obviaron algunas de ellas, subsiste la principal, á su juicio, esto es que ignora la Corporación si el precio ofrecido es suficiente, porque no se ha consultado á persona competente y desinteresada sobre el valor de los objetos". El arcipreste propuso que se comisionara a un canónigo para desplazarse a Madrid y pedir opinión al padre Fidel Fita, de la Academia de la Historia ${ }^{43}$. El deán advirtió entonces "la desairada situación en que quedara él y el Ilmo. Cabildo después de la promesa formal hecha al Sr. Lafora, el cual según carta dirigida al Sr. Deán saldría aquel mismo día de Madrid con dirección á Zamora siendo portador de la cantidad estipulada". La falta de acuerdo propició la celebración de un cabildo extraordinario el día siguiente 23 de febrero, para tratar sobre el asunto.

A aquella reunión asistieron los señores deán, arcipreste, arcediano, maestrescuela, doctoral, lectoral, penitenciario y los canónigos Hernández, Fernández, Otero, Mateos, Palacios, Muriel, Chillón y el secretario Eduardo Leal, citados por el pertiguero para el día 23 al término de las horas canónicas. Tras la lectura de la citación: "el sr. Deán declaró cual era el motivo de aquella sesión extraordinaria, tratar del asunto urgente y que había quedado pendiente de resolución en la sesión precedente relativo a la venta de los objetos antiguos ya citados. Preguntó á la Corporación si se aceptaba el precio ofrecido por $D$. Juan Lafora y se contestó afirmativamente por todos, exceptuado el Sr. Arcipreste que emitió su voto por escrito, pidiendo se archive pues por las razones anteriormente expuestas se cree obligado en conciencia a no hacerse solidario de la referida venta. Tomado acuerdo de la venta, por mayoría, se designó una Comisión formada por los Sres Deán, Fabriquero, Contadores y Secre-

\footnotetext{
${ }^{43}$ Se trata del historiador y jesuita Fidel Fita y Colomer (1835-1917).
}

tario para recibir de D. Juan Lafora el precio convenido y entregarle los objetos" 44 .

El mismo día 23 de febrero, justo un año después de que el cabildo acordara vender las arquetas, junto a otros objetos, se entregaron las cajas al anticuario, como consta en el Libro de Contaduría del Cabildo: "Febrero 23. Entregó D. Juan Lafora por dos cajas (Sr. Dean, Maestrescuela, Leal y el que suscribe) 52.500 ptas.". Cinco días más tarde el Cabildo adquiría varios títulos de la Deuda pública, "los cuales' costaron cincuenta y dos mil quinientas ' pesetas 'y veinte céntimos... cuya cantidad se aplica por igual á Mesa Capitular y Fábrica" ${ }^{45}$

Años más tarde, en 1926, las restantes arquetas árabes que no habían sido vendidas en 1911, fueron a parar " $a$ un coleccionista madrileño [Pedro Castillo Olivares], sin formalidades legales: huelgan los comentarios", según el indignado comentario de Gómez Moreno en su Catálogo Monumental.

\section{EL "REDESCUBRIMIENTO" DEL BOTE DE ZAMORA POR GÓMEZ MORENO.}

Apenas unos días después de que Lafora se llevase a Madrid sus codiciadas preseas un golpe de suerte hizo cambiar el rumbo (y el destino) de los acontecimientos.

Corría un día de marzo - recuerda $\mathrm{M}^{\mathrm{a}}$ Elena Gómez-Moreno- cuando al llegar su padre a la Junta de Ampliación de Estudios se encontró con sus amigos arabistas Julián Ribera y Miguel Asín Palacios que le ense-

\footnotetext{
44 Archivo catedralicio de Zamora. Actas Capitulares. Lib. 56. Cabildo extraordinario de 23 de febrero de 1911, fol. 228.

45 Archivo catedralicio de Zamora. Libro de contaduría 19911-1913. Constan las series y números de los títulos, así como su valor. Al margen va escrito: "Estos títulos y las 3500 pts de D. Fernando Iglesias, se subieron al Tesoro hoy 3 de marzo de 1911".
} 
ñaron la copia de un letrero en árabe que les habían llevado para traducirlo. GómezMoreno lo reconoció de inmediato: la inscripción del bote de Zamora.

Ellos le dijeron que se lo había entregado una persona conocida, cuyo nombre silenciaron, con encargo expreso de que no se enterara Guillermo de Osma. Para D. Manuel las cosas -subraya nuestra autoraestaban muy claras: el bote había salido de Zamora y estaba en manos de anticuarios cuyo propósito, sin duda, era venderlo en Estados Unidos. El ilustre granadino conocía bien "el afán del cabildo zamorano para convertir en dinero las pertenencias de la catedral, y de ello tenía pruebas repetidas". El temor a que el bote saliese del país le hizo apresurarse en llevar la noticia a Osma que, como coleccionista y político, era el único capaz de poder abortar la situación.

Hacia 1901, año de la muerte de Juan Facundo Riaño, su primer gran valedor en Madrid, Gómez-Moreno entabló relación con Guillermo de Osma con quien quedó definitivamente ligado hasta su muerte, a pesar del difícil carácter de ambos. Era entonces Osma diputado y amigo del Ministro de Instrucción Pública, Conde de Romanones y su asesor privado en materia de Bellas Artes. El conocimiento entre Osma y Gómez-Moreno vino a través del círculo de Riaño, por el erudito sevillano José Gestoso y por el numismata menorquín Antonio Vives, principal colaborador en las andanzas arqueológicas de Osma que presentó a ambos en la casa del político, palacete de la C/ Fortuny donde tenían lugar unas animadas tertulias dominicales, charlas y té a la inglesa, a las que asistían los susodichos arabistas Ribera y Asín, Gestoso, E. Tormo, M. González Simancas, Vives etc.

Guillermo Joaquín de Osma y Scrull (1853-1922), de entronque inglés por su madre se educó en la Sorbona y Oxford donde se graduó de Magister Artium. Siguió la carrera diplomática (1877-1891) para después ser ininterrumpidamente elegido diputado por Monforte de Lemos (Lugo) por la fracción política conservadora (Partido Conservador) maurista. Desempeñó asimismo varios cargos políticos: subsecretario del Ministerio de Ultramar en 1895 y Ministro de Hacienda durante los gobiernos Maura de 1903-1904 y 1907-1908. En 1919 se le nombró senador vitalicio y Presidente del Consejo de Estado. Fue además miembro de la Academia de Ciencias Morales y Políticas, de la de BB. AA. de San Fernando y de la Buenas Letras de Barcelona.

Casó con Dña. Adelaida Crooke, hija única del malagueño de origen británico Juan Bautista Crooke y de la Condesa de Valencia de Don Juan, diplomático, arqueólogo, director de la Real Armería, académico de la historia y experto coleccionista de artes decorativas, sobre todo cerámica islámica con especial dedicación a la de reflejo metálico. Este coleccionismo atípico, como señala Barrio Moya ${ }^{46}$, orientó el gusto de su yerno, pues además de la cerámica (y eboraria) andalusí Osma se interesó por objetos marginales de lo que era el gusto de la época: encajes, telas, bordados, azabaches etc. Un conjunto excepcional que configuró el denominado Instituto Valencia de Don Juan, fundado en 1916, sito en el mismo palacete de la calle Fortuny y del que más tarde, llegaría a ser director, durante muchos años, el propio Gómez-Moreno.

G. de Osma y A. Crooke, XXIIII Condesa de Valencia de Don Juan, no legaron sus colecciones al Estado, del que no se fiaban, sino a una Fundación elitista regida por un patronato para "servir a los que vayan a sabiendas y con voluntad", "museo", pues, de acceso muy restringido, como sigue siéndolo hasta la fecha.

\footnotetext{
${ }^{46}$ J.L. MOYA; “Un coleccionista atípico: Don Guillermo Joaquín de Osma", Goya, 267, 1998, pp. 364-374
} 
El prestigio político y cultural de Osma y las especiales relaciones que mantenía con Gómez-Moreno explican que el estudioso granadino, haciendo oídos sordos a las advertencias de Ribera y Asín, se apresurase en transmitirle la noticia ante el fundado temor de que el bote saliese de España. No lo localizó, pero le dejó una nota, mientras buscó a Ribera para sonsacarle el nombre del portador del letrero, un tal señor Gargollo, marqués de Valverde: "coleccionista y chamarilero por lo fino", apostilla María Elena Gómez-Moreno, contertulio no sólo de Osma en el palacete de Fortuny sino de Lafora en la Carrera de San Jerónimo. Se explica así que cuando Osma leyó la misiva, telefoneó furioso a Gómez-Moreno, furor que arreció al conocer el nombre del interesado. Envió inmediatamente la noticia y foto al ABC, escribió al nuncio y contó lo sucedido al presidente de gobierno, Canalejas, y a su jefe de partido, Maura; por fin, telegrafió al gobernador y obispo de Zamora y preparó una intervención en el Congreso de los Diputados.

\section{LA POLÉMICA EN LAS CORTES.}

La polémica llegó a las Cortes en un momento de especial sensibilización pública tanto por la crisis en las relaciones Iglesia-Estado, como por los escándalos en la enajenación del patrimonio eclesiástico.

En primer lugar, ambas instituciones atravesaban momentos de fuerte tensión, por la denominada "Ley del Candado" de 1910, contra la que se sucedieron duros ataques desde las publicaciones católicas y concentraciones y mítines organizados por algunos prelados y entidades confesionales ${ }^{47}$. El propio Cabildo zamorano elevó su particular queja: y en su reunión de $1^{\text {o }}$ de

\footnotetext{
${ }^{47}$ M. CUENCA TORIBIO, “El catolicismo español en la Restauración (1875-1931)", en R. GARCÍA VILLOSLADA (dir): Historia de la Iglesia en España, V. Madrid 1979, pág. 283.
}

julio de 1910 acordó formular y elevar "á las Cortes enérgica protesta contra las medidas y propósitos del actual Gobierno que tienden á menoscabar los intereses de la Religión y los derechos de la Iglesia" ${ }^{\prime 4}$.

Por otro lado, el clima en que se desarrolló la polémica en las Cortes se encontraba extremadamente caldeado por asuntos patrimoniales. De 1910 a 1914 se celebraron, por primera vez en España, varias sesiones de Cortes a propósito de la venta de la Epifanía de Monforte de Hugo Van der Goes al Kaiser Guillermo II. La suerte del cuadro ${ }^{49}$ llegó a apasionar de tal forma a la opinión pública que el affaire pasó desde la Cámara Baja al terreno de la prensa y al Ateneo. Algunos de los protagonistas del "caso Zamora" desempeñaron también un importante papel en los rifirrafes sobre la tabla del gran maestro flamenco.

Cuando los escolapios de Monforte de Lemos, vendida la pintura, (con el refrendo del Duque de Alba, patrono del Colegio fundado por el cardenal D. Rodrigo de Castro en el siglo XVI) se preparaban a exportar la tabla en junio de 1910, el nombramiento de Julio Burrell como Ministro de Instrucción Pública que sucedía al inoperante Conde de Romanones (por lo demás director de la Real Academia de San Fernando) supuso la incautación gubernativa del cuadro, desde entonces vigilado por la Guardia Civil. Un acto insólito, recuerda Gaya Nuño, en la desgraciada historia de expoliaciones de nuestro patrimonio.

Esta actitud valiente, que ponía en solfa las posibles reclamaciones diplomáticas del gobierno alemán, no se correspondió con la actitud de G. J. de Osma, diputado por Monforte de 1891 a 1919 que, a dife-

\footnotetext{
${ }^{48}$ Archivo catedralicio de Zamora. Actas capitulares. Lib. 156. Palabra de $1^{\circ}$ de julio de 1910, fol. 201 r. y v.

${ }^{49}$ GAYA NUÑO, 1960, Apéndice II, pp. 105-118.
} 
rencia de su aguerrida reivindicación del bote de Zamora, mantuvo respecto a la pintura una posición de absoluta tibieza.

Peores consecuencias trajo el asesinato del presidente del Consejo de Ministros J. Canalejas (12/XI/1912) para el desenlace final del tinglado. Canalejas que, como veremos más adelante, había lograda salvar para el Museo Arqueológico Nacional el bote zamorano, estaba igualmente dispuesto a impedir la evasión de la Epifanía de Van der Goes. Su sucesor, el Conde de Romanones, que como Ministro de Instrucción Pública ya había rechazado la adquisición del cuadro por el Estado, no puso más empeño en el asunto que el de resolverlo cuanto antes y dar por buena la venta con tan poderoso cliente como era el Imperio Alemán. Una suscripción pública in extremis para allegar la misma cantidad que había pagado el Kaiser no tuvo éxito (al revés de lo que los ingleses habían hecho en 1910 para impedir que la Venus del espejo pasase a manos francesas), cuestación a la que Romanones no aportó ni un duro. Otra propuesta muy controvertida fue la de intercambiar la pieza por un bufón de Velázquez, que quedó también en agua de borra$\mathrm{jas}^{50}$. Todo fue en vano. A principios de enero de 1914, la Epifanía de Van der Goes, una de las obras maestras del siglo $\mathrm{XV}$, embarcó en Vigo rumbo a Hamburgo.

De vuelta a las arquetas zamoranas los hechos se suceden con gran precipitación durante tres días claves para la resolución del caso. El 10 de marzo, ante la noticia y foto del $\mathrm{ABC}$ se armó el escándalo, recuerda María Elena Gómez-Moreno, dándose por seguro que el bote había cruzado ya el Atlántico. A la interpelación de Osma en el Congreso se sumó la de Elías Tormo en el Senado al plantear que, si la ley no

${ }^{50}$ A. CASTRO MARTín; “Villegas-Lázaro. Una difícil relación", Goya 288, 2002, pp. 136-138. ponía coto, el tesoro artístico español iría saliendo al extranjero sin remedio.

En su larga intervención parlamentaria, no exenta de retórica, Osma comunicó que los canónigos de Zamora acababan de vender una caja de marfil del año 955, "la última que quedaba en España, de las cuatro análogas que hasta nuestro tiempo habían llega$d o^{\prime \prime}$, pues las otras tres habían ido a parar a museos foráneos ${ }^{51}$. Reprochó a los capitulares zamoranos que bien podrían haber seguido el ejemplo del Cardenal Primado de España que, en situaciones análogas, había ofrecido al Estado la opción y el derecho de tanteo y, a continuación, dio lectura a un telegrama que le había sido remitido por "autoridad competente", del que se reservó el nombre. El telegrama decía: "Ofrecido preferentemente al Estado objeto de venta hace ocho meses, y no contestando, entendióse rehusaba adquirirlo. Urgentes necesidades decidieron Cabildo, usando de su derecho, venderlo á un español, previa autorización pontificia. Consú-

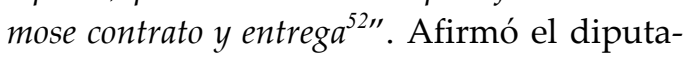

\footnotetext{
${ }^{51}$ Ma E. GómEZ-MORENO, 1995, p. 243 da otra versión de los hechos: "Al llegar la noticia [del $\mathrm{ABC}$ ] a Zamora el cabildo se asustó y pidió a Osma que lo defendie$r a$, pues había actuado legalmente. Y el obispo contestó con un insolente telegrama, que Tormo leyó en el Senado, callando la firma". Mientras - prosigue María Elena- Antonio Vives dijo estar enterado desde hacía meses del asunto y que se lo había comunicado un anticuario amigo, Rafael Lafora, que había adquirido el bote y otras tres arquetas de la catedral en 10000 duros echándole irónicamente la culpa a Gómez-Moreno por descubrir a los canónigos su valor y no haberse quedado con él.

${ }^{52}$ Según la misma autora: MaE. GÓMEZ-MORENO, 1995 , p. 243, decidida por el cabildo la venta del bote y conseguido el permiso reglamentario de Roma, se comunicó el asunto al Ministerio de Gracia y Justicia, del que dependía todo lo relacionado con la Iglesia, y se ofreció la pieza al Estado por medio del cuerpo de Archivos, no obteniéndose respuesta. Pasó el tiempo y el cabildo, impaciente, negoció la operación con Lafora en secreto, sin comunicárselo al Ministerio. El anticuario facilitó el bote a dos personas, una de ellas Gorgollo, quienes se encargarían de su venta en Estados Unidos. Por suerte el Marqués de Valverde copió el letrero del bote para su traducción por Asín y Ribera,
} 
do Osma que él era testigo de que el Gobierno había telegrafiado al gobernador de Zamora, para que recabara información del Cabildo y solicitara la preferencia de adquirir las arquetas por parte del Estado; por todo ello, solicitaba del Presidente del Consejo de Ministros la apertura de una investigación y de información sobre "dónde se extravió aquel ofrecimiento preferente que no llegó hasta el Gobierno". Asimismo, suplicaba al Gobierno que por vía diplomática confirmara si la Santa Sede había dado autorización para la venta y que si en esa autorización se especificaba alguna condición.

Tras la intervención del diputado, tomó la palabra para responder el Presidente del Consejo de Ministros, José Canalejas. Comenzó reconociendo que no conocía los detalles del procedimiento seguido por el Cabildo de Zamora, que haría la pregunta por vía diplomática a la Santa Sede y que había que evitar la repetición de casos semejantes. Canalejas fue tajante y rotundo: el ofrecimiento del ejercicio del derecho de tanteo al Estado no podía consumar la venta; además, continuaba, "no puedo admitir que la mera tenencia, la mera posesión por parte del Cabildo, por parte de cualquier institución religiosa, de una joya semejante, le autorice á venderla libremente; si es cosa sagrada, está fuera del comercio de los hombres; si es patrimonio nacional, debe ser garantizado por la eficacia del ejercicio de la intervención del Poder público... no puede ejercitarse ni por los Cabildos ni por nadie ( $y$ ahora hablamos de los Cabildos) ese jus abutendi". Canalejas aprovechó su disertación para abogar por la necesidad de realizar una catalogación de los objetos artísticos, poniendo como ejemplo a seguir el catálogo impreso realizado por la iglesia catedral de Toledo, para concluir afirmado que "una nación tiene que defender sus riquezas artísticas, que son legado de la historia,

momento en el que, providencialmente, GómezMoreno lo "redescubre." tejidas en muy complejas relaciones, y que eso hay que resolverlo con imperio de Poder público, con energía de Poder público, imponiéndose á todas las codicias y á todos los abusos".

Seguidamente intervino el diputado Senante ${ }^{53}$, quien hizo una defensa a ultranza de lo que él entendía el derecho de la Iglesia "para disponer como bien le parezca de todo aquello que constituye su legítimo patrimonio" sin tener que ajustarse más que a lo prescrito por el derecho canónico. Justificaba la venta de los tesoros para atender a las necesidades apremiantes de la Iglesia, dada la penuria que atravesaba en España. Reprochaba al Estado no atender a dichas necesidades "que echó sobre sus hombros cargas que á la Iglesia antes cometían y que al despojarle de sus bienes tuvo aquél que aceptar, aunque constantemente evade ahora cumplir", en clara referencia a las políticas desamortizadoras y liberales. En apoyo de la actuación del Cabildo zamorano, Senante recordó que los capitulares lo habían puesto en conocimiento del Estado y que este "dió la callada por respuesta". Para el diputado estaba justificadísima la conducta del Cabildo de enajenar la pieza, argumentado que en la diócesis de Zamora había habido "necesidad de reparar en poco tiempo más de 200 iglesias que estaban enteramente ruinosas, y para esas reparaciones sólo ha habido subvención del Estado para siete ú ocho... á pesar de ser el Estado quien tiene la obligación, desatendida casi siempre, de atender á la reparación de los templos". Concluyó diciendo que "la Iglesia tiene derecho perfectísimo por mucho que queráis ponerlo

\footnotetext{
53 Manuel Senante y Martínez (Alicante 1873Madrid 1958) fue diputado a Cortes por la fracción política integrista por el distrito de Azpeitia, desde 1907 hasta su disolución por el Directorio de Primo de Rivera en 1923. Abogado y periodista ultraconservador, su actividad parlamentaria es "una página de lucha ininterrumpida en defensa de los intereses de la religión y la patria". Enciclopedia Universal Ilustrada europeoamericana. Tomo XL. Barcelona 1927, p. 214.
} 
en tela de juicio, á disponer de lo suyo para atender á sus necesidades" ${ }^{54}$.

Tras una breve intervención de nuevo de Osma, la opinión del diputado Senante fue replicada por Canalejas quien, sin querer entrar directamente en materia, advirtió que sobre "la necesidad de la venta para conservar los templos habría mucho que hablar", pues "el bien comunal eclesiástico no es sólo de los Prelados ó de los Cabildos ó de los sacerdotes, sino del común de los fieles..." ${ }^{55}$

Estaban pues muy claras las posturas de sus señorías: unas claramente a favor de la conducta seguida por el Cabildo de Zamora y, por tanto, defensora del derecho de la Iglesia a disponer de su patrimonio y otra, la del gobierno de Canalejas, expuesta por el propio presidente, que postulaba la intervención del poder público en la defensa de las riquezas artísticas de la Nación. En cualquier caso, en el fondo del debate latían las difíciles relaciones Iglesia-Estado del momento. El propio Canalejas era consciente de ello en sus intervenciones, cuando decía: "Suplico a la Cámara que no atribuya ni á la indignación del Sr. Osma, más lejos que yo de tal sospecha, ni á la mía, que por desgracia puedo sentirme comprendido en la sospecha, el alcance de nada que transcienda á problema religioso ni á tibiezas con la Iglesia. Hablamos del Cabildo de Zamora, como hablaríamos de cualquier Corporación laica" y, más adelante: "De modo que no hay parcialidad, ni pasión, ni sectarismo, que me estoy temiendo ya que todos estos comentarios sirvan de cortejo á mis pobres palabras, dichas con toda sinceridad" ${ }^{\prime 56}$.

El asunto se siguió tratando en la cámara los días 11 y 13 de marzo y 8 de

\footnotetext{
${ }^{54}$ Diario de Sesiones del Congreso, 10 de marzo de 1911, número 5, p. 61.

${ }^{55}$ Diario de Sesiones del Congreso, 10 de marzo de 1911, número 5, p. 62.

${ }^{56}$ Diario de Sesiones del Congreso, 10 de marzo de 1911, número 5, p. 59.
}

mayo. En la sesión del día 11 intervinieron el diputado Burell ${ }^{57}$, que había sido Ministro de Instrucción Pública en el momento en que se produjo el contacto con el Estado, el Ministro de la Gobernación (Mariano Alonso Castrillo Bayón) y el diputado Osma. Según Julio Burell, la oferta del Cabildo de Zamora se trató en la sesión que la Junta Superior de Archivos y Bibliotecas celebró el 12 de diciembre de 1910 y que, por tanto, quedó en manos de dicha Junta cuando él dejó el Ministerio. Lo primero que debía averiguar el Gobierno, en opinión del ex ministro, es si la caja de marfil había salido de Zamora (compara la situación con la del cuadro de Van der Goes de Monforte y la de otros varios del Greco que, procedentes de Toledo, habían emigrado del país).

En esos momentos, realmente el Gobierno ignoraba el paradero exacto de la caja, como se desprende de la respuesta del ministro de la Gobernación: "esa caja está vendida, y aun creo que fuera de España; yo no lo sé". A continuación, Burell le indica que existe "la posibilidad de que la caja no esté

\footnotetext{
${ }^{57}$ Julio Burrell y Cuéllar, Iznájar (Córdoba) 1859Madrid 1919. Periodista y político, desde su llegada a Madrid en 1874 se distinguió pronto en el Ateneo como fogoso y vehemente polemista. Como periodista su prosa enérgica y vibrante, sus vistosas y temperamentales imágenes hicieron de él una personalidad originalísima en los periódicos de la época: El Progreso, Nuevo Heraldo, La Opinión etc. Diputado a Cortes desde 1887, primero por La Coruña y Pontevedra y desde 1905 por Jaén, fue evolucionando desde el campo republicano al monárquico liberal. Según consta en los archivos del Congreso de los Diputados perteneció primero a la fracción política demócrata del Partido Liberal y finalmente a la garcía-prietista. Durante los gobiernos liberales desempeñó importantes cargos públicos: gobiernos civiles, direcciones generales y ministerios, de Fomento, Gobernación y sobre todo de Instrucción Pública y Bellas Artes en tres ocasiones: 9/VI/1910 a 2/I/1911; 9/XII/1915 a 9/IV/1917 y 9/XI/1918 a 5/XII/1918. Ver: Enciclopedia Universal Ilustrada Europeo-Americana, T. IX, Barcelona, pp. 1432-1433. Precisiones políticas y cronológicas, de éste y otros personajes, son gentileza de la Presidencia del Congreso de los Diputados, a la que queremos dejar constancia de nuestro agradecimiento.
} 
fuera de España, sino en Madrid" y que el asunto merece ser investigado por la policía; aprovechando su intervención para reprochar al Cabildo de Zamora que "ha cometido un abuso de confianza; eso pertenece á la Nación española". El ministro Castrillo anuncia la apertura de la investigación policial y confirma que "la venta se ha verifica$d o^{\prime \prime}$ según le ha comunicado el gobernador civil de Zamora, así como que en junio o julio se puso el hecho en conocimiento de los ministerios de Instrucción Pública y de Gracia y Justicia. Burell solicita la oportunidad de que el Cabildo declare el nombre del comprador para saber el paradero de la caja. El temor de que el recipiente de marfil pudiera salir fuera de España, le lleva a requerir además al Gobierno para que dirija un telegrama a los gobernadores civiles medida anunciada por Castrillo-, y "uno muy especial á los de las fronteras". Seguidamente intervino el diputado Osma para asociarse al ruego de Burell, de que el expediente que se hubiera tramitado sobre la oferta al Gobierno se llevara a la Cámara, advirtiendo que en el asunto no se trataba sólo de "aquella caja histórica, sino de otras tres más pertenecientes al tesoro, y aun al relicario de la propia catedral" 58 .

El día 13, respondiendo a una pregunta previa del Sr. Osma sobre la situación del bote zamorano, el presidente Canalejas confirma que "la caja en cuestión y otra de menos importancia que pertenecía tambien al tesoro artístico de la misma catedral se encuentran en Madrid"59 y que ambas cajas quedarían depositadas en poder del Estado al día

\footnotetext{
${ }^{58}$ Las intervenciones del día 11 de marzo véanse en el Diario de Sesiones del Congreso, número 6, pp. 8889.

${ }^{59}$ Diario de Sesiones del Congreso, sesión de 13 de marzo de 1911, número 7, pp. 104-105.
}

siguiente, lo que le vale la felicitación más calurosa de G. de Osma." ${ }^{60}$.

\section{LA COMPRA DE LAS ARQUETAS POR EL ESTADO.}

En efecto, tal como informaba la prensa provincial, el día 14 de marzo las cajas habían sido trasladadas al Museo Arqueológico Nacional, comprándoselas al anticuario Lafora por la misma cantidad en que éste las había adquirido ${ }^{61}$.

Al decir de Mํㅡㄹ E. Gómez-Moreno, el alboroto y sospecha de que el bote había salido de España empujo a Lafora a presentarse a Canalejas asegurándole que la pieza seguía en Madrid y que él no era sino un mero intermediario. El resto de la historia se puede seguir a través del Expediente de adquisición por el Estado de dos arquetas de Zamora, año 1912, número 78. Museo Arqueológico nacional. $51944^{62}$.

El mismo día 13 de marzo de 1911 se firma el acto de entrega en depósito de las dos obras, pendientes de pago por el Estado, al Museo Arqueológico Nacional en casa del mismísimo presidente del Consejo de Ministros D. José Canalejas. Asisten al acto, además del anticuario Lafora, distintos miembros del Museo, del Ministerio de Instrucción Pública y BB. AA y el propio G. J. de Osma. Al día siguiente, 14 de marzo, las dos cajitas zamoranas ingresan en el MAN a pesar de que su "adquisición por el Estado está en trámite".

El 8 de mayo de ese año, ya estaba el expediente en el Congreso, pues en el Diario de Sesiones se recoge que "quedaron sobre la Mesa, á disposición de los señores Diputa-

\footnotetext{
${ }^{60}$ Diario de Sesiones del Congreso, sesión de 8 de mayo de 1911, pág. 692.

${ }^{61}$ El Correo de Zamora, 14 de marzo de 1911.

${ }^{62}$ Gentileza de Doña Ángela Franco, conservadora del Museo Arqueológico Nacional.
} 
dos...el expediente sobre adquisición propuesta al Estado por el Cabildo-catedral de Zamora, de dos cajitas antiguas de carácter mudéjar, enviado por el Sr. Ministro de Instrucción pública, á petición de los Sres. Burell y Osma".

Por Real Decreto de 20 de junio de 1911 se dispuso, por fin, la adquisición de las dos arquetas por el precio de 52500 pesetas, una por 25000 y otra por 27500 , efectuándose el primer pago de 25000 ptas el 29 de octubre de 1912.Todavía un escrito de 12 de mayo $^{63}$ de 1913 del Subsecretario del Ministerio de Instrucción Pública (que recoge texto del Ministro) indica: que estaba pendiente de pago una de las arquetas adquiridas a D. Juan Lafora; que se abonen por tal concepto 27500 pesetas con cargo a las 32000 (sic) consignadas expresamente para este servicio (pago que se ejecuta el 22 de octubre de 1913); y que se interese del Cabildo Catedral de Zamora de sus derechos de propiedad sobre las arquetas y si en todo caso procedió a su venta con la autorización debida y, en caso contrario, se entablen las acciones y ejerciten los derechos que legalmente procedan contra el Cabildo.

Por fin el 18 de mayo de 1914 por orden del Rey se abonan a Don Juan Lafora 5028,46 pts como intereses de demora de la cantidad de 52500 en que fueron adquiridas las arquetas.

Estos pasos, con la desesperante lentitud de la Administración, no coinciden (al menos en el fondo y origen de la financiación) con la versión de la hija de GómezMoreno, María Elena, cuyas noticias, sin duda de primera mano, procederían del archivo paterno. Según nuestra autora, " $e l$ Estado, como de costumbre, carecía de fondos" para indemnizar a Lafora. "Ante ello Osma se puso al habla con su amigo Mr. Hunting-

${ }^{63}$ Esa parece ser la fecha oficial, pero al margen aparece la 11 de junio de 1913. ton ${ }^{64}$...para aportar cada uno venticinco mil pesetas y adquirir el bote, que regalan al Museo

${ }^{64}$ Aunque no haya ninguna otra cita que lo avale, su propio curriculum sería suficiente para considerarlo más que verosímil. Archer Milton Huntigton (18701955) fue miembro de una familia americana de magnates y coleccionistas de arte: Collis Potter Huntington (1821-1900), fundador de la compañía de ferrocarriles Central Pacific Railroad y de los astilleros Newport News Shipbuilding and Drydock Company, Arabella Duval Huntington (1850-1924) y Henry Edwards Huntington (1850-1927). La figura clave como coleccionista es la de Arabella, casada con Collis desde 1884 hasta su muerte y con Henry, sobrino de aquel, desde 1913. Archer fue hijo único (e ilegítimo) de Arabella y Collis y de ella heredó la pasión por el arte y los libros. De las instituciones culturales promovidas por la familia destacan dos: la Henry E. Huntington Library and Art Gallery, establecida en San Marino, próximo a Los Ángeles (California), especializada en alta bibliografía británica y americana y pintura inglesa del siglo XVIII y la Hispanic Society de Nueva York, creada por Archer M. Huntington en 1904 y dedicada al arte y cultura hispánica (ibérica y americana) sin olvidar más 17000 libros anteriores a 1701, un fondo documental inencontrable fuera de España. Archer fue el más filantrópico de los Huntington, fundando y patrocinando numerosas entidades, la más importante de las cuales fue la Hispanic Society, debido a su pasión por España, a la que dedicó todos sus empeños desde los 15 años hasta su muerte. En Estados Unidos realizó multitud de fundaciones benéficas, museísticas y medioambientales, entre otras, el Museum of the American Indian y la American Academy of Arts and Letters, ambas en Nueva York, el Mariners' Museum and Brook green Gardens en South Carolina, etc. En España recibió las condecoraciones más prestigiosas del país, fue miembro de las Academias de la Historia, de la Lengua y de la Sevillana de Buenas Letras y del patronato del Instituto Valencia de Don Juan, entre otras instituciones, colaboró en la creación de las Casas de Cervantes (Valladolid) y del Greco (Toledo), llevó a cabo excavaciones en Itálica, financió la Revue Hispanique (París 19051933), donó cuadros, publicó facsímiles de ejemplares inencontrables y promovió la edición de decenas de libros sobre el arte y la cultura española. Sobre Huntington y la Hispanic Society, véase: VV.AA. The Hispanic Society of America. 1904-1954, Nueva York 1954.B. Gilman Procke; Archer Milton Huntington, Nueva York 1963 (edición castellana, Nueva York 1965).M. A. Codding; "Archer Milton Huntington, paladín de España en América", en Sorolla y la Hispanic Society, Catálogo de la Exposición, Madrid 1998, pp. 91-117 (texto realizado a partir de los diarios y archivos de Huntington). P. E. Muller; "La España amada de Huntington en América. Los tipos, los trajes y el pueblo", 
Arqueológico Nacional, a más de otra arqueta árabe de marfil, decorada en el siglo XVI con pinturas de angelitos".

A continuación y como consecuencia de todo ello, añade, "Osma redacta una Real Orden por la cual todos los tesoros de las iglesias debían ser inventariados y prohibirse su venta; habian de crearse museos diocesanos o catedralicios, con subvención del Estado, en los que aquellos se expusieran debidamente. En adelante toda venta exigiría trámites que lo harían, no sólo ilegal, sino casi imposible".

Huelgan los comentarios salvo que lo consideremos una inocentada.

En cualquier caso, resuelto el affaire, Gómez-Moreno, indignado con sus amigos zamoranos que no le habían informado, rompió con ellos, recuerda María Elena, y escribió un artículo sobre el bote ofrecido al $A B C$, que lo rechazó por excesivamente científico y que publica $L a$ Época ${ }^{65}$.

\section{LA POLÉMICA EN LA PRENSA ZAMORANA.}

La prensa, tanto en Madrid (El País, El Mundo, ABC, El Imparcial, El Universo, La Mañana, La Ilustración Española y Americana) como en Zamora (El Heraldo de Zamora, El Correo de Zamora) siguió las andanzas y el debate sobre las arquetas, justificando o criticando el proceder de los canónigos, según el distinto credo ideológico del rotativo. La zamorana, eco de la de la capital, sintió también, de forma más viva, los argumentos enfrentados. Por su carácter más directo nos referiremos exclusivamente a ella.

en De Goya a Zuloaga. La pintura española de los siglos XIX y XX en The Hispanic Society of America, Catálogo de la Exposición, Madrid, 2000, pp. 15-25.

${ }^{65}$ M. Gómez MORENO, "Arqueta de Zamora", La Época. Reimpreso en el libro de E. LeguinA, Arquetas hispano-árabes, Madrid 1912 , pp. 53-65.
Para el diario tradicionalista-católico El Correo de Zamora, el Cabildo había obrado de acuerdo con "su perfectísimo derecho á disponer de sus bienes conforme al Derecho de la Iglesia, para remediar necesidades urgentes á que no podía atender de otro modo". La noticia la suministró El Correo el sábado día 11 de marzo bajo el título "Sobre una venta de objetos de arte". Califica de "términos alarmantes" las intervenciones de los diputados Osma y Tormo, así como de "aparentes indignaciones" la de Canalejas. Luego, se ocupa de las arquetas, a las que define de "estilo mudéjar", que el cabildo no podía usar para nada "a pesar de ser de algun valor artístico porque estaban muy deterioradas por el tiempo". Alude a la petición del Ministerio de Gracia y Justicia cursada al Cabildo para que las cajas fueran mostradas en una exposición internacional de Munich, a lo que se negaron los canónigos por temor a que se estropearan totalmente, al tiempo que comisionaban al señor Ruiz Valarino para que ofreciera las cajas al Estado "si éste quería adquirirlas, pues al Cabildo le urgían apremiantes atenciones". Informa el diario que el 6 de julio, el deán y cabildo enviaron una instancia al Ministerio de Gracia y Justicia "reiterando el ofrecimiento al Estado de las arquetas, por las cuales se habían llegado a ofrecer hasta cincuenta mil pesetas". Sobre el particular, continua El Correo, el Boletín Oficial del ministerio en su número 14 publicó extracto de la citada instancia disponiendo que esta pasase al ministerio de Instrucción Pública y Bellas Artes. El periódico denuncia el desinterés del ministro Burell, ocupado como Canalejas, "con lo de la sarna y la lepra á causa de las manifestaciones católicas que se preparaban contra el gobierno", por lo que "no se acordó para nada de la instancia del Dean de Zamora, la cual no dió contestación alguna como tampoco su sucesor D. Amós Salvador". Fue en estas circunstancias, al decir de El Correo de Zamora, cuando un comerciante español (y subraya, "no extranjero") que había visto fotografías de una arqueta hizo ofrecimientos al 
Cabildo, el cual, obtenida la autorización pontificia, vendió la caja á mediados de Febrero últi$m o^{\prime \prime}$. Reitera el diario que dicha venta está "perfectísimamente justificada no solo por el indisputable derecho de todo propietario á enajenar sus bienes para atender a sus necesidades, sino porque además no hay disposición alguna que lo prohíba, aunque si existiera sería abusiva por constituir un ataque intolerable al derecho de propiedad". Para el diario católico, el gobierno había abandonado el asunto y Canalejas era un fariseo que se rasgaba las vestiduras "fingiendo indignaciones para la galería". Concluye diciendo que si la caja estaba en Estados Unidos sería responsabilidad en todo caso del comprador y arremete finalmente, sin citarlo, contra Osma: “... hemos oído decir que quien más ha hablado en este asunto en Madrid adquirió una caja igual hace unos años en una catedral española sin que se sepa si la vendió ó no á algún extranjero, pero constando que entonces no tuvo interés en divulgar al noticia".

Se equivocaba El Correo de Zamora al asegurar que la caja había salido de España con dirección a los Estados Unidos, aunque a punto estuvo. Tres días más tarde, el rotativo informaba que la caja artística había sido trasladada al Museo Arqueológico Nacional y que se había comprado al anticuario Lafora por 52.500 ptas $^{66}$.

Tono y argumentos muy distintos emplea El Heraldo de Zamora, de ideología liberal, que se ocupó ampliamente del asunto, días 11, 13, 14 y 16 de marzo. Este último publicó en portada un magnífico fotograbado del bote de marfil, con el título " $\mathrm{La}$ célebre arqueta", lo que no era nada usual, pues lo común era que las ilustraciones fueran meros dibujos. En la información del día 11 con el título "Zamora en las cortes", El Heraldo hace un extenso resumen de la se-

${ }^{66}$ El Correo de Zamora, 11 y 14 de marzo de 1911. sión del día 10 en el Congreso, con las intervenciones de Osma, Canalejas y Senante.

El lunes 13 nuestro diario publica también en portada un extenso artículo titulado "Sobre el relicario vendido", con tres partes: una "Zamora en las Cortes y en la Prensa"; otra "Información local" y la tercera, "La arqueta está en Madrid".

Comienza la primera haciéndose eco de la atención que la prensa madrileña (entre ellas el $A B C$ que reprodujo el fotograbado de la arqueta) viene dedicando a la denuncia formulada por el diputado conservador señor Osma en el Congreso. Pondera a continuación la calidad de la pieza, lamentándose de que "esa joya artística, haya como tantas otras en estos últimos años, desaparecido de España". Después de citar que, según El Mundo, fueron consoladoras las palabras del presidente del Consejo, El Heraldo, en la línea expuesta por Canalejas, defiende las razones del Estado para ejercer $\mathrm{su}$ "derecho preferente sobre aquellas obras en que los cabildos son meros depositarios de la voluntad de personas cuyos legados fueron hechos por fieles". Argumenta asimismo, como había hecho Osma, que la caja había encerrado las reliquias de un santo. Para el periódico el Cabildo no podía vender lo que eran joyas compradas por particulares que fueron legadas en custodia bajo la vigilancia tutelar del Estado. Otro de los argumentos utilizados por El Heraldo es la riqueza artística de España (de lo que habla el periódico La Mañana) que, bien administrada, podría hacer del país "uno de los focos de atracción más poderosos para el turismo mundial".

La segunda parte se ocupa de la pregunta que el señor Calamita, director de $E l$ Heraldo, hizo al señor obispo sobre la venta de las arquetas y de las razones que éste le dió sobre el tenor, "con el fin de remediar, con su producto, urgentes necesidades que de otro modo se veía imposibilitado (el Cabildo) de 
atender". Por último, el diario informaba que el bote estaba en Madrid, en manos de don Juan Lafora, propietario de una tienda de antigüedades establecida en la Carrera de San Jerónimo, 51 y que el anticuario se había puesto a disposición de Gobierno para darle una solución al asunto.

De nuevo volvió El Heraldo sobre la arqueta en la edición del martes 14 de marzo, con una extensa información y comentario. En el apartado "Zamora en las Cortes y en La Prensa", informa de la reunión de la Academia de la Historia bajo la presidencia de Menéndez Pelayo, donde se trató de la enajenación de la caja ebúrnea zamorana y de la necesidad de evitar por todos los medios posibles la completa desaparición de los bienes artísticos y arqueológicos. Alude también a que Canalejas contestó a Osma que la caja ya estaba en poder del Estado e incorpora una noticia, aparecida en $\mathrm{ABC}$, según la cual el Cabildo zamorano habría vendido igualmente otros objetos artísticos que formaban parte de su relicario. Más adelante reproduce un artículo de Mariano de Cavia aparecido en El Imparcial, en el que, partiendo del anhelo de P.J. Proudhon por la destrucción de Museos y Catedrales, califica como "hecho brutal que los seglares, regulares y capitulares, señorones viciosos y Cabildos codiciosos, están haciendo tabla rasa de todo el artístico legado de la España histórica". Cavia, entre otras cosas, concluía: "Con la venta de la arqueta ebúrnea de la catedral de Zamora -un caso entre diez mil- se ha hecho traición á la causa cristiana, pues que era la arqueta un sagrado relicario; á la pía voluntad del donante, pues no se donó la joya para que se vendiera á mercaderes; á España, en fin, por ser prenda de un arte neta y genuinamente español". Terminaba El Heraldo con el apartado de "Información local", dando cuenta de la visita que el director había hecho al Deán. Se quejaba el periódico de la escasa información suministrada por el sacerdote que, se había limitado a reconocer la venta de dos cajas, el precio pagado por el anticuario
Lafora, el acuerdo unánime del Cabildo ${ }^{67}$, la precaria situación económica de la Corporación, la autorización pontificia y el ofrecimiento previo al Ministerio de Gracia y Justicia.

El tratamiento que hizo El Heraldo de Zamora de la venta de las arquetas molestó al Cabildo. El día 18 de marzo el canónigo Mateos, encargado de la lectura de la prensa, citó a "palabra" a los capitulares, a los que expuso su disgusto por la publicación que el citado periódico había hecho sobre la venta de las cajas antiguas, conducta que calificó de "poco noble... porque después de acudir al Sr. Obispo y Presidente del Cabildo solicitando datos bajo pretexto de defender á la Corporación é informar con veracidad al público, nada ha hecho de lo primero y en cuanto á lo segundo ha transcrito de periódicos sectarios sus informaciones falsas, con la acostumbrada argumentación sofística, crudeza de estilo y lenguaje mordaz que usan con predilección en sus ataques a la Iglesia". En consecuencia, se acordó designar "á los señores arcediano y Chillón para redactar un artículo que se insertará en el periódico católico de esta ciudad "El Correo de Zamora" y si la ley de imprenta obliga á ello en el mismo Heraldo de Zamora" ${ }^{68}$. Sin embargo la respuesta no se llevó a efecto, pues tal y como informó el arcediano en la reunión del Cabildo de 29 de marzo, El Heraldo, en los días siguientes a la polémica publicación, transcribió la información del diario católico El Universo, por lo que entendía que carecía de fundamento la gestión encomendada, acordándose quedara en suspenso "por si surgiera nuevamente".

\footnotetext{
${ }^{67}$ Recordemos que el Arcipreste se opuso a la venta.

${ }^{68}$ Archivo catedralicio de Zamora. Actas capitulares. Lib. 156. Palabra del 18 de marzo de 1911, fol. 230 v.
} 


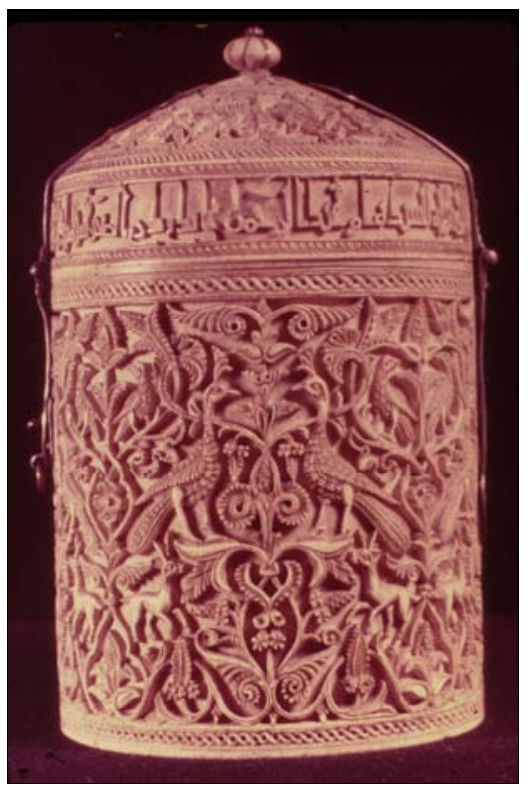

- Lám. I. Bote de Zamora, Museo Arqueológico Nacional, Madrid.

(arriba izquierda)

- Lám. II. Bote y arqueta de Zamora. Según N. Sentenach; La Ilustración Española y Americana, 22 de marzo de 1911.

(abajo centro)

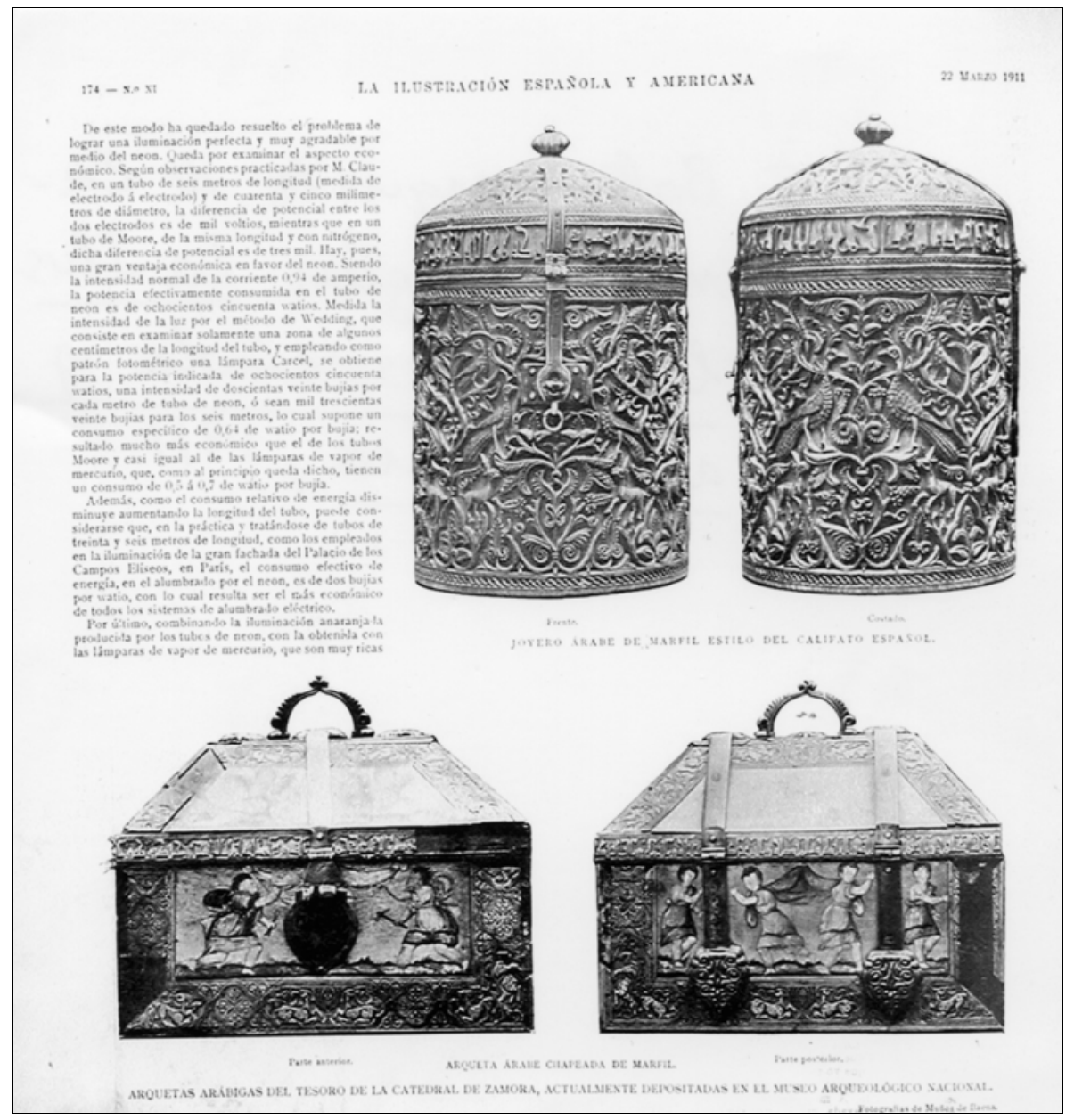

